\title{
ANALISIS KESULITAN SISWA DALAM MENYELESAIKAN SOAL CERITA MATEMATIKA PADA MATERI KELILING DAN LUAS LINGKARAN SMPN 3 NARMADA DITINJAU DARI PETA KOGNITIF
}

\author{
Nellyda Andriani ${ }^{1}$; Sutarto ${ }^{2}$; Baiq Rika Ayu Febrilia ${ }^{3}$ \\ ${ }_{1,2,3}$ Pendidikan Matematika, FPMIPA, IKIP Mataram
}

\begin{abstract}
Abstrak
Tujuan penelitian ini adalah untuk mendeskripsikan kesulitan-kesulitan yang dialami siswa dalam menyelesaikan soal cerita pada materi keliling dan luas lingkaran SMPN 3 Narmada ditinjau dari peta kognitif. Penelitian dilakukan di SMPN 3 Narmada. Subjek penelitian ini terdiri dari 2 subjek di kelas IX C SMPN 3 Narmada. Jenis penelitian ini adalah penelitian deskriptif kualitatif. Instrument yang digunakan adalah soal tes dan pedoman wawancara. Teknik pengumpulan data yang digunakan adalah teknik tes dan wawancara. Analisis data mengacu pada pendapat Miles dan Huberman adalah reduksi data, analisis data, dan kesimpulan. Hasil penelitian menunjukkan bahwa kesulitan yang dihadapi siswa sebagai berikut: kesulitan memahami soal yaitu siswa tidak bisa mengubah soal kedalam bentuk matematika, kesulitan merencanakan penyelesaian yaitu siswa tidak bisa menemukan langkah-langkah yang digunakan untuk menyelesaikan soal, kesulitan melaksanakan perencanaan yaitu siswa sering melakukan kesalahan dalam menggunakan pengoperasian perkalian dan pengurangan, kesulitan dalam memeriksa kembali solusi yang diperoleh yaitu siswa tidak bisa menyelesaikan permasalahan secara tepat dan hasil jawaban akhir tidak sesuai dengan konteks soal.
\end{abstract}

\section{Kata Kunci: Kesulitan, Peta Kognitif}

\section{PENDAHULUAN}

Matematika merupakan ilmu hitung berupa angka yang menjadi sarana dalam kehidupan sehari-hari yang membantu manusia dalam menyelesaikan masalah. Matematika perlu diajarkan kepada siswa karena selalu digunakan dalam segi kehidupan, semua membutuhkan keterampilan matematika dan matematika dapat meningkatkan kemampuan berpikir logis (Ardiyanti, 2014).

Matematika masih dianggap sebagai mata pelajaran yang sulit dan tidak menyenangkan oleh banyak siswa, bahkan sejumlah siswa menganggap matematika sebagai hal yang menakutkan, kemudian pandangan tersebut menyebabkan siswa mengalami kesulitan dalam belajar matematika sehingga siswa juga sulit dalam menyelesaikan soal matematika terutama pada soal cerita (Julianti, 2016). Meskipun demikian, semua orang harus mempelajari matematika karena matematika merupakan suatu sarana untuk memecahkan masalah dalam kehidupan sehari-hari. Dari hasil wawancara yang dilakukan guru kelas VIII SMPN 1 Narmada, SMPN 3 Narmada dan setelah dilihat dari beberapa jurnal, masih banyak siswa yang mengalami kesulitan dalam mempelajari materi lingkaran dan siswa masih sering melakukan kesalahan dalam mengerjakan soal cerita. Menurut pendapat Wibowo (2016) kesulitan-kesulitan siswa dalam menyelesaikan soal cerita dapat dilihat dari kesalahan yang dilakukan siswa dalam proses menyelesaikan soal cerita. Oleh karena itu pentingnya 
kita mencari tau kesulitan siswa yaitu untuk memudahkan guru dalam membuat strategi pembelajaran yang tepat untuk siswa dan untuk mengurangi banyaknya kesalahan yang dilakukan siswa.

Soal cerita matematika adalah soal terapan dari pokok bahasan matematika yang disajikan dalam bentuk kalimat dan dikaitkan dengan kehidupan sehari-hari (Juliyanti, 2016). Soal cerita merupakan soal yang berbentuk cerita dalam matematika yang terkait dengan kehidupan sehari-hari untuk dicari penyelesaianya menggunakan kalimat matematika yang memuat simbol.

Kesulitan-kesulitan yang dialami siswa dalam menyelesaikan soal cerita menurut Wibowo (2016) kesulitan dalam memahami soal, kesulitan merancanakan penyelesaian masalah, kesulitan dalam melaksanakan perencanaan penyelesaian masalah, kesulitan pengambilan kesimpulan jawaban.

Langkah-langkah dalam pemecahan masalah matematika dalam bentuk soal cerita menurut Polya (dalam Hidayah, 2016) yaitu: memahami masalah, merencanakan pemecahan masalah, melaksanakan rencana pemecahan masalah, dan memeriksa kembali solusi yang diperoleh.

Adanya kesulitan siswa dalam menyelesaikan soal matematika perlu mendapat perhatian lebih (Utami, 2017). Salah satu yang menyebabkan belum maksimalnya hasil belajar siswa yaitu kesalahan-kesalahan yang dilakukan oleh siswa dalam mengerjakan soal (Zahara, 2016). Jika kesulitan siswa dalam menyelesaikan soal dibiarkan, maka tujuan pembelajaran tidak akan tercapai dengan baik dan akan berdampak pada prestasi belajar siswa di sekolah.

Salah satu materi pembelajaran yang membuat siswa kesulitan dalam belajar yaitu pada materi lingkaran. Materi lingkaran merupakan salah satu materi pokok dalam matematika yang erat kaitannya dalam kehidupan sehari-hari (Sutriningsih, 2015). Banyak permasalahan-permasalahan dalam kehidupan sehari-hari yang memerlukan pemahaman konsep lingkaran dalam pemecahannya. Namun faktanya, materi ini merupakan salah satu kajian matematika yang dianggap sulit untuk dipahami oleh siswa.

Berdasarkan uraian-uraian tersebut dapat diteliti dan dikaji lebih lanjut bagaimana kesulitan siswa dalam menyelesaikan soal cerita. Untuk mengetahui bentuk kesulitan tersebut perlu dianalisis kesalahan siswa dalam menyelesaikan soal cerita keliling dan luas lingkaran pada pembelajaran matematika kelas IX.C SMPN 3 Narmada. Hal ini bertujuan untuk menganalisis kesulitan-kesulitan yang dialami siswa.

\section{METODE PENELITIAN}

Jenis penelitian yang digunakan adalah penelitian deskriptif dengan pendekatan kualitatif. Bungin (2007) deskriptif adalah bertujuan untuk menggambarkan, meringkaskan berbagai kondisi, berbagai situasi, atau berbagai fenomena realitas sosial yang ada di masyarakat yang menjadi objek penelitian, dan berupa menarik realitas itu ke permukaan sebagai suatu ciri, karakter, sifat, modal, tanda, atau gambaran tentanng kondisi, situasi, ataupun fenomena tertentu. Menurut pendapat 
Sugiyono (2015) metode penelitian kualitatif adalah metode penelitian yang digunakan untuk meneliti pada kondisi yang alamiah, dimana peneliti sebagai instrumen kunci, objek pengumpulan data dilakukan secara triangulasi.

Subjek dalam penelitian ini adalah siswa kelas IX.C di SMPN 3 Narmada. Peneliti memilih 2 siswa sebagai pembanding. Dari 2 siswa yang terpilih akan mewakili siswa yang lain untuk di wawancara.

Instrumen dalam penelitian ini adalah instrumen utama dan instrumen bantu. Instrumen utama dalam penelitian adalah peneliti itu sendiri dan instrumen bantu dalam penelitian ini adalah soal tes dan pedoman wawancara. Dalam penelitian ini teknik pengumpulan data yang digunakan adalah teknik tes teknik wawancara.

Teknik analisis data yang digunakan peneliti untuk menganalisis data kualitatif yang bersifat induktif yaitu reduksi data, penyajian data, dan penarikan kesimpulan.

\section{HASIL DAN PEMBAHASAN}

Penelitian ini dilaksanakan pada tanggal 20 September 2018 di SMPN 3 Narmada. Adapun hasil penelitian yang dilakukan oleh peneliti adalah sebagai berikut :

\section{Hasil}

a) Deskripsi data $S a$

1) Soal 1

Pemaparan data dalam menyelesaikan masalah subjek $S a$ kesulitan dalam memahami soal yang diberikan untuk menyelesaikan soal cerita keliling dan luas lingkaran. Subjek $S a$ Kesulitan dalam Memahami Soal (KMS), ini ditandai dengan hasil pekerjaan siswa. Ketika subjek Sa disuruh menggambar lingkaran yang mempunyai diameter 140, subjek $S a$ menggambar sebuah lingkaran yang diinginkan peneliti, namun ketika subjek ditanya "mana yang disebut dengan diameter ?" subjek $S a$ menjawab "tidak tau". Kemudian peneliti menunjuk gambar yang telah digambar oleh subjek $S a$ dan peneliti bertanya lagi “ini disebut dengan apa ?" subjek $S a$ menjawab "garis", peneliti bertanya lagi “ ini kan lingkaran, ada tidak diameternya ?" subjek sa menjawab "tidak ada". Dari pernyataan subjek $S a$, bahwa siswa tidak memahami soal yang diberikan. Hal ini ditunjukkan dari hasil pekerjaan siswa dan hasil wawancara yang terlihat pada gambar dibawah ini.

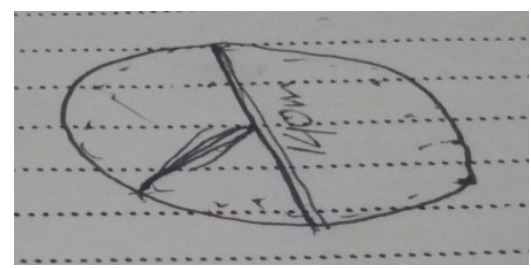

Gambar 1. Lembar Jawaban Subjek $S a$ 
$P \quad:$ coba perhatikan gambar yang adek buat, mana yang disebut dengan diameter?

$\mathrm{Sa}$ : tidak tau

$P \quad:$ tadi kan kakak suruh gambar lingkaran yang ada berdiameter

Sa : iya

$P \quad$ : lingkaran ini ada tidak diameternya?

$\mathrm{Sa}$ : tidak ada

Selanjutnya dalam mengerjakan soal subjek $S a$ juga mengalami Kesulitan dalam Merencanakan Penyelesaian (KRS). Ketika siswa pertama kali melihat soal yang diberikan peneliti, peneliti mengamati bahwa subjek $S a$ tampak kebingungan dalam merencanakan penyelesaian. Subjek $S a$ tidak tau cara mencari biaya keseluruhan lampu hias. Dalam lembar jawaban subjek $S a$, terlihat bahwa subjek $S a$ tidak bisa merencanakan penyelsaian. Langkah pertama yang dilakukan subjek $S a$ yaitu mengalikan diameter 140 dengan biaya pemasangan satu lampu hias 11.000. Kemudian subjek $S a$ melihat kembali soal yang diberikan, ternyata ada jarak antar setiap tiang lampu adalah 8 meter. Sehingga subjek $S a$ menjumlahkan jarak tiang dengan hasil perkalian diameter dan biaya pemasangan satu lampu hias sehingga ketemu hasil keseluruhan biaya pemasangan lampu hias yaitu 140 x $11+8=1$ 548.000. Setelah subjek $S a$ mendapatkan hasil keseluruhan biaya pemasangan, kemudian subjek $S a$ mencari berapa lampu yang dipasang dalam lingkaran. Subjek $S a$ berfikir jika pemasangan satu lampu hias adalah 11.000 maka jika dipasang 2 lampu berati biayanya 22.000, jika dipasang 4 lampu maka biayanya 44.000, sehingga siswa menuliskan bahwa banyak lampu yang akan dipasang adalah 88 lampu. Hal ini menunjukkan bahwa subjek $S a$ kesulitan dalam merencanakan penyelesaian. Seperti yang terlihat dalam gambar hasil pekerjaan subjek $S a$ dan kutipan wawancara yang dilakukan peneliti terhadap subjek $S a$ yang ditunjukkan dalam gambar dibawah ini.

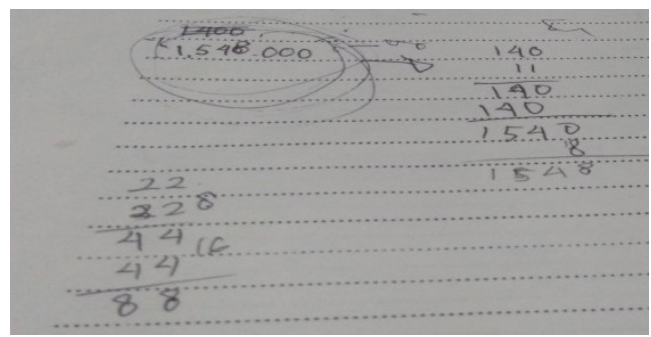

Gambar 2. Lembar Jawaban Subjek $S a$

$P \quad:$ bagaimana caranya menghitung biaya keseluruhan?

S2 : geleng-geleng

$P \quad:$ di dalam lembar jawaban adek kan udah ada jawabannya. Bagaimana caranya adek mendapatkan jawabannya?

S2 $: 140 \times 11=1.540 .000$

$P \quad: 1.540 .000$ adalah keseluruhan biayanya?

S2 : iya

$P \quad:$ kemudian jaraknya di apain?

S2 : di tambah sehingga hasilnya 1548 adalah biaya keseluruhan 
Selanjutnya dalam mengerjakan soal, subjek $S a$ juga mengalami kesulitan dalam melaksanakan perencanaan (KLR). Subjek Sa pertama kali melihat soal, yang difikirkan adalah 11 x 140 sehingga menghasilkan 1400. Siswa tidak bisa mengalikan apa yang direncanakan. Ketika peneliti menanyakan dari mana dapat 1400, siswa menjawab 140 x 11 . Hal ini dapat dilihat dari lembar jawaban subjek $S a$ dan hasil wawancara yang dilakukan peneliti terhadap subjek $S a$, yang terlihat dalam gambar dibawah ini.

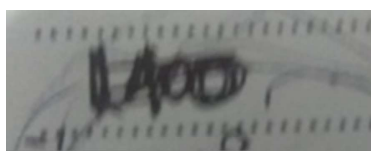

Gambar 3. Lembar jawaban subjek $S a$

$P:$ dalam lembar soal adek, ini berapa?

$S 2: 1400$

$P:$ dapat dari mana?

$S 2: 11 \times 140$

Selanjutnya dalam mengerjakan soal, subjek $S a$ juga Kesulitan dalam Pengambilan Kesimpulan (KMS). Subjek $S a$ menuliskan jawaban akhir akan tetapi tidak sesuai dengan konteks soal atau jawaban yang diberikan tidak sesuai dengan yang diinginkan peneliti. Kesulitan subjek $\mathrm{Sa}$ dalam dalam pengambilan kesimpulan yaitu ditandai dengan adanya jawaban akhir yang tidak sesuai. Seperti yang dipaparkan dalam gambar dan hasil wawancara peneliti terhadap subjek $S a$, seperti yang terlihat dalam gambar dibawah ini.

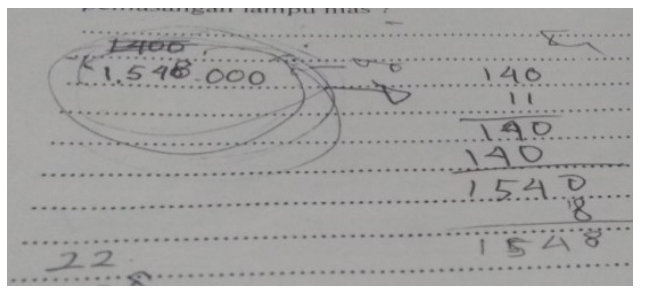

Gambar 4. Lembar jawaban subjek Sa

$P$ : di dalam lembar jawaban adek kan udah ada jawabannya. Bagaimana caranya adek mendapatkan jawabannya?

Sa $: 140 \times 11=1.540 .000$

$P: 1.540 .000$ adalah keseluruhan biayanya?

Sa : iya

2) Soal 2

Pemaparan data dalam menyelesaikan masalah subjek $S a$ pada soal nomor 2 yaitu kesulitan dalam memahami soal yang diberikan untuk menyelesaikan soal cerita keliling dan luas lingkaran. Dalam soal nomor 2 Subjek $S a$ mengalami Kesulitan dalam Memahami Soal (KMS). Hal ini dilihat dari hasil pekerjaan subjek $S a$ dan hasil wawancara yang dilakukan peneliti terhadap subjek $S a$. Dalam soal yang diberikan, subjek $S a$ tidak bisa membedakan apa yang yang ditanyakan dan apa yang diketahui. Di dalam soal sudah jelas bahwa ada jari-jari berukuran 14 
meter, namun subjek $S a$ menganggap itu adalah yang ditanyakan dari soal. Kemudian dalam lembar jawaban subjek $S a$ terdapat lingkaran dan 8 jari-jari. Subjek $S a$ menganggap bahwa hanya 8 jari-jari yang terdapat dalam sebuah lingkaran. Subjek $S a$ tidak paham mengenai jari-jari lingkaran. Seperti yang terlihat dalam gambar dan hasil wawancara peneliti terhadap subjek $S a$ sebagai berikut:

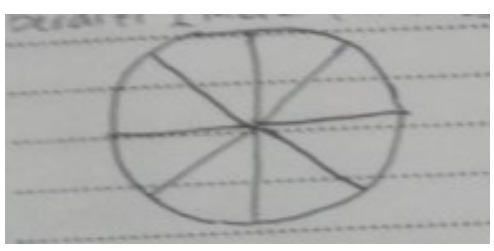

Gambar 5. Lembar Jawaban Subjek $S a$

$P \quad$ : apa yang adek ketahui dari soal ini ? adek ngerti dengan soal ini ?

$\mathrm{Sa}$ : sedikit

$P \quad$ : sedikitnya itu dimana?

$S a \quad$ : sedikitnya itu di jari-jarinya

$P \quad$ : berapa jari-jarinya?

$\mathrm{Sa}: 14$ meter

$P \quad: 14$ meter itu disebut diketahui atau ditanyak?

$\mathrm{Sa}:$ ditanyakan

Selanjutnya dalam mengerjakan soal, subjek $S a$ juga Kesulitan dalam Merencanakan Penyelesaian (KRS). Untuk mencari luas dari taplak meja yang tidak diletakkan mangkuk, subjek $S a$ mencari luas mangkuknya terlebih dahulu. Subjek $S a$ mengalikan diameter mangkuk dengan jari-jari untuk menghasilkan luas mangkuknya yaitu 15 meter. Setelah subjek $S a$ menemukan luas mangkuknya, selanjutnya subjek $S a$ akan mencari luas taplak meja yang tidak diletakkan mangkuk yaitu dengan mengurangi luas mangkuk 15 meter dan jari-jari 14 meter, sehingga menghasilkan 1 meter. Seperti yang terlihat pada gambar dan hasil wawancara peneliti terhadap subjek $S a$ sebagai berikut :

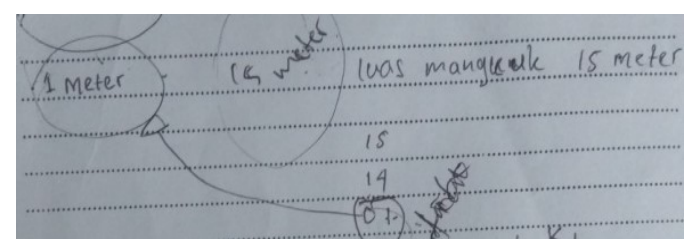

Gambar 6. Lembar Jawaban Subjek $S a$

$P \quad:$ kalau kita kalikan 0,7 dengan 14, bisa tidak kita temukan luas yang tidak diletakkan mangkuk ?

S2 : 15 meter luas semuanya

$P \quad$ : luas keseluruhan buat yang mana? taplak meja atau mangkuk?

S2 : mangkuk

Selanjutnya dalam menyelseaikan soal, subjek $S a$ juga Kesulitan dalam Melaksanakan Perencanaan (KLR). Subjek $S a$ kesulitan dalam melaksanakan perencanaan yang dibuat sendiri. subjek $S a$ 
memilih operasi yang digunakan untuk menyelesaikan soal, namun subjek $S a$ salah dalam menjumlahkan hasilnya. Subjek $S a$ mengalikan 0,7 dengan 14, namun hasilnya tidak sesuai dengan hasil sebenarnya. Subjek $S a$ tidak bisa mengalikan dan menjumlahkan dengan benar. Seperti yang terlihat dalam gambar dan hasil wawancara peneliti terhadap subjek $S a$, sebagai berikut :

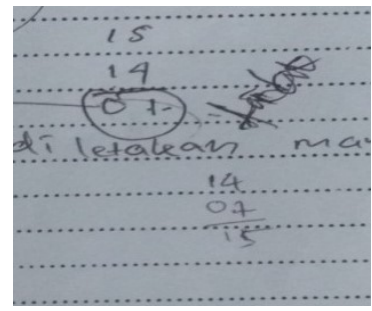

Gambar 7. Lembar Jawaban Subjek $S a$

$P$ : untuk mencari luas taplak meja yang tidak diletakkan mangkuk, langkah awal apa yang harus kita lakukan?

Sa : 0,7 dikali dengan 14

$P$ : hasilnya berapa?

$\mathrm{Sa}: 15$ meter

Selanjutnya dalam mengerjakan soal, subjek $S a$ juga Kesulitan dalam Pengambilan Kesimpulan (KPK). Subjek $S a$ tidak bisa mengambil kesimpulan untuk mencari luas dari taplak meja yang tidak diletakkan mangkuk, subjek $S a$ menuliskan hasil akhir jawaban, namun tidak sesuai dengan konteks soal. Subjek $S a$ tidak menuliskan dengan benar hasil akhir jawaban seperti yang dituliskan dalam lembar jawaban subjek $S a$. Subjek $S a$ menuliskan dalam lembar jawabannya bahwa 15 meter adalah luas mangkuk dan 1 meter adalah luas yang tidak diletakkan mangkuk. Hal ini dapat dilihat dari gambar dan hasil wawancara peneliti terhadap subjek $S a$, sebagai berikut:

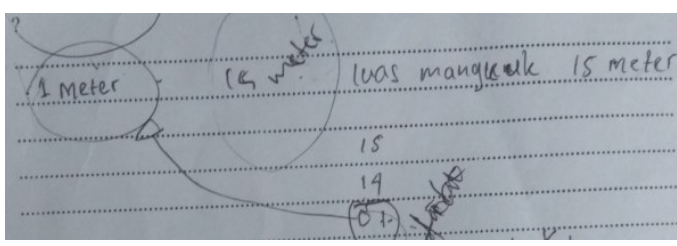

Gambar 8. Lembar Jawaban Subjek $S a$

$P \quad:$ dari 15-14 yang yang tadi ? berarti 1 meter ini apanya?

$\mathrm{Sa}$ : luas yang tidak diletakkan mangkuk.

b) Deskripsi data $S b$

1) Soal 1

Pemaparan data dalam menyelesaikan masalah subjek $S b$ pada soal nomor 1 yaitu kesulitan dalam memahami soal yang diberikan untuk menyelesaikan soal cerita keliling dan luas lingkaran. Dalam soal nomor 1 Subjek $S b$ mengalami Kesulitan dalam Memahami Soal (KMS). Subjek $S b$ mengalami kesulitan dalam memahami soal. Hal ini dapat dillihat dari hasil wawancara yang 
dilakukan peneliti terhadap subjek $S b$, seperti yang dilihat dalam kutipan wawancara sebagai berikut :

$P \quad$ : yang diketahui dari soal ini sebenarnya apa?

$S b$ : diameter lingkaran dan jarak antara lampu hias

$P \quad$ : Cuma itu yang diketahui ?

$\mathrm{Sb}:$ : iya

Selanjutnya dalam menyelesaikan soal subjek $S b$ juga mengalami Kesulitan dalam Merencanakan Penyelesaian (KRS). Untuk menyelesaikan soal mencari keseluruhan biaya pemasangan lampu hias subjek $S b$ mencari rumus diameter yaitu $\frac{22}{7} \times 140=440$ selanjutnya subjek mengalikan $22 \times 20 \times 8=3.420$. Subjek $S b$ bingung dengan diameter dan jarak lampu hias. Subjek $S b$ tidak tau apa yang harus dicari sebelum menemukan biaya keseluruhan lampu hias, kemudian subjek $S b$ menyelesaikan soal dengan menggunakan rumus diameter. Hal ini dilihat dari gambar dan hasil wawancara peneliti terhadap subjek $S b$, sebagai berikut :

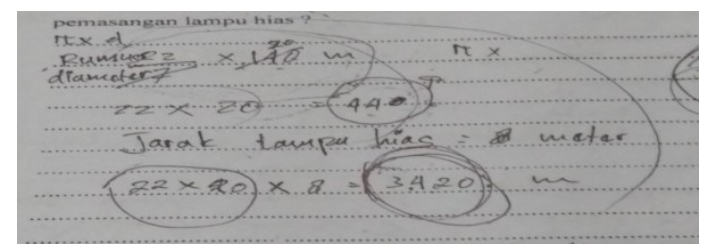

Gambar 9. Lembar Jawaban Subjek $S b$

$P$ :bagaimana caranya kita menyelesaikan soal ini?

$S b$ : bingung

$P$ : bingungnya dimana?

$S b:$ yang diameter

$P:$ ada apa dengan diameternya ? tau namanya diameter?

Sb : iya

$P$ : terus bingungnya dimana?

Sb : jarak antar lampu

Selanjutnya dalam menyelesaikan soal, subjek $S b$ juga mengalami kesulitan dalam Melaksanakan Perencanaan (KLR). Dalam menyelesaikan soal subjek $S b$ kesulitan dalam melaksanakan perencanaan yang telah dibuat. Dalam lembar jawaban subjek $S b$, terlihat bahwa subjek tidak bisa mengalikan angka yang digunakan. Subjek $S b$ mengalikan $22 \times 20 \times 8=3.420$. Hal ini dapat dilihat dalam gambar dan hasil wawancara subjek $S b$, sebagai berikut:

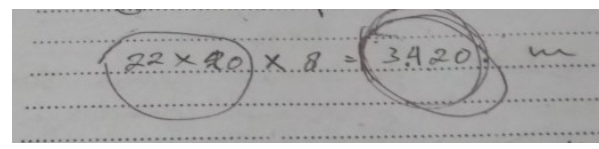

Gambar 10. Lembar Jawaban Subjek $S b$

$P$ : apakah adek yakin dengan jawaban adek?

$S b:$ yakin

$P$ : coba liat 3.420 ini apa? 
Sb : biaya keseluruhan, $22 \times 20 \times 8=3.420$

Selanjutnya dalam menyelesaikan soal, subjek $S b$ juga mengalami Kesulitan dalam Pengambilan Kesimpulan (KPK). Subjek $S b$ mengerjakan soal, namun tidak sesuai dengan konteks soal atau tidak sesuai dengan yang diharapkan oleh soal. Subjek $S b$ sudah bisa menemukan rumus diameter, akan tetapi dalam mengambil kesimpulan subjek $S b$ mengalami kesulitan. Seperti yang terlihat dalam gambar dan hasil wawancara peneliti terhadap subjek $S b$, sebagai berikut:

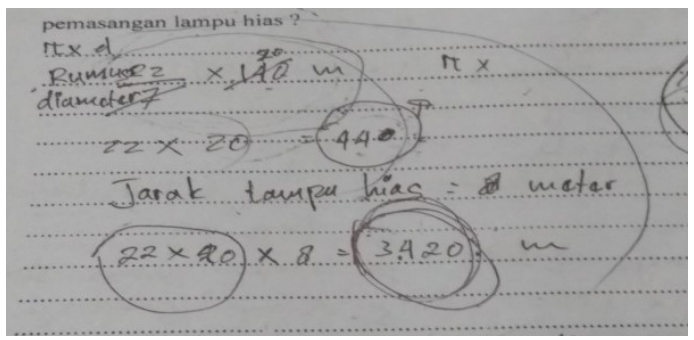

Gambar 11. Lembar Jawaban Subjek $S b$

$P \quad$ : apakah adek yakin dengan jawaban adek?

$\mathrm{Sb}$ : yakin

$P \quad$ : coba liat 3.420 ini apa?

$\mathrm{Sb}$ : biaya keseluruhan, $22 \times 20 \times 8=3.420$

2) Soal 2

Paparan dalam hasil lembar jawaban subjek $S b$ bahwa subjek $S b$ mengalami kesulitan dalam memahami soal. Subjek $S b$ tidak paham dengan soal yang diberikan. Ketika Subjek $S b$ ditanya apa yang diketahui dalam soal, subjek $S b$ menjawab hanya diameterlah yang diketahui. Hal ini dilihat dari petikan hasil wawancara subjek $S b$, sebagai berikut :

$P$ : apa yang diketahui dari soal?

$S b$ : jari-jarinya 14 meter

$P$ : itu aja?

Sb : iya

Selanjutnya dalam menyelesaikan soal subjek $S b$ juga kesulitan dalam merencanakan penyelesaian (KRS). Subjek sb menggunakan rumus $\pi \times r$ untuk mengetahui luas taplak meja yang tidak diletakkan mangkuk, sehingga menghasilkan $\frac{22}{7} \times 14=44$. Subjek sb tidak tau rumus yang digunakan dalam mencari luas dari taplak meja yang tidak diletakkan mangkuk jika jari-jarinya diketahui. Subjek sb kebingungan dalam menyelesaikan soal yang diberikan. Seperti yang terlihat dalam gambar dan hasil wawancara peneliti terhadap subjek sb,sebagai berikut :

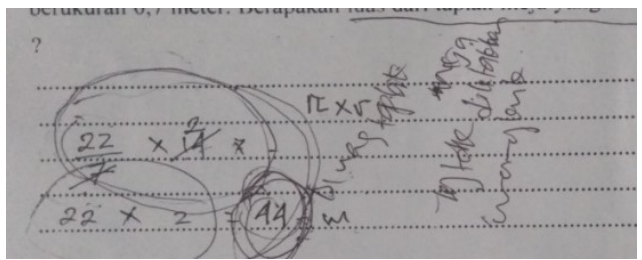

Gambar 12. Lembar Soal Subjek Sb

$P$ : apa yang harus dicari untuk mengetahui taplak meja yang tidak diletakkan mangkuk? 
S3 : cari hasil jari-jarinya

Selanjutnya dalam menyelesaikan soal subjek sb juga Kesulitan dalam Melaksanakan Perencanaan (KLR) ini ditandai dengan hasil pekerjaan siswa. Dalam menyelesaikan soal yang diberikan, subjek sb mencari biaya keseluruhan dengan menggunakan rumus $\pi \times r$. Dilihat dari lembar jawaban subjek sb, tampak kebingungan dalam mencari luas yang tidak diletakkan mangkuk. Siswa mencoba mencari jumlah luas keseluruhannya, namun subjek sb bingung bagaimana cara mencari jumlahnya. Seperti yang terlihat dalam kutipan wawancara sebagai berikut :

$P$ : luas taplak meja yang mana ? kan tadi udah ketemu luas yang tidak diletakkan mangkuk

$S 3$ : jumlah keseluruhannya bingung

$P$ : adek bingung gimana mau dicari ?

S3:iya

$P$ : untuk mencari luasnya apa sih rumusnya jika diketahui jari-jarinya?

S3 : lupa

Selanjutnya subjek sb juga mengalami kesulitan dalam penarikan kesimpulan. Seperti yang terlihat dalam lembar jawaban subjek sb. Dalam hal ini, subjek sb menuliskan langkah-langkah dalam menyelesaikan soal, akan tetapi jawaban subjek sb tidak sesuai dengan yang diinginkan peneliti. Subjek sb tidak bisa mencari luas taplak meja yang tidak diletakkan mangkuk. Siswa sangat yakin dengan jawaban yang ia tulis pada lembar jawaban, namun subjek masih sangat kebingungan dengan soal yang diberikan. Seperti yang terlihat dalam gambar dan hasil wawancara peneliti terhadap subjek $s b$, sebagai berikut :

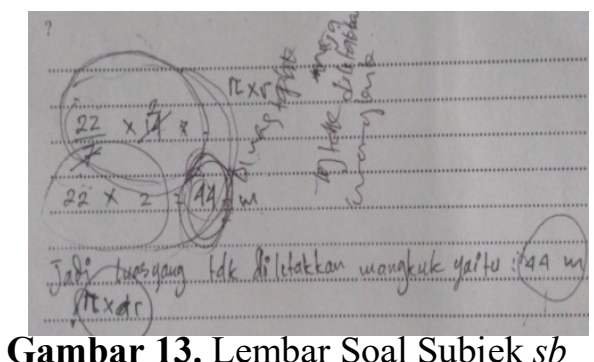

$P: 44$ disebut nilai apa?

S3 : nilai jari-jari dari taplak meja

$P:$ terus jawabannya apa? yakin dengan jawabannya

S3 : tidakyakin

\section{PEMBAHASAN}

Pada bagian ini akan dideskripsikan tentang kesalahan siswa dalam menyelesaikan soal cerita keliling dan luas lingkaran pada subjek $S a$ dan subjek $S b$. Pada subjek $S a$ dan $S b$ dalam menyelesaikan soal cerita nomor 1 dan nomor 2 dilihat dari jawaban siswa terlihat bahwa siswa tidak mampu menentukan penyelesaian yang diharapkan. Ini menunjukkan bahwa siswa tidak memahami permasalahan dalam soal. Dari analisis terhadap lembar jawaban dan hasil wawancara dapat dikatakan 
bahwa siswa kesulitan dalam menfokuskan pikiran, lupa rumus-rumus dalam mencari keliling dan luas lingkaran.

Untuk masalah soal nomor 1 dan 2, subjek Sa dan Sb menunjukkan bahwa Sa dan Sb memulai dengan melihat permasalahan yang diberikan kemudian menghitung setiap yang diketahui pada soal. Subjek Sa dan Sb tidak bisa menyelesaikan permasalahan yang diberikan karena subjek Sa dan Sb tidak mengingat pelajaran yang diajarakan pada kelas sebelumnya, subjek Sa dan Sb tidak mengingat atau lupa rumus untuk mencari keliling dan luas lingkaran. Hal ini sejalan dengan pendapat Gafoor dan Kurukkan (2015) menyimpulkan bahwa siswa kesulitan dalam mengingat materi yang diajarkan pada kelas sebelumnya, cepat melupakan materi belajar dan kesulitan dalam memahami konsep-konsep matematika.

Dalam menyelesaikan soal Subjek Sa dan Sb mengalami kesulitan dalam menyelesaikan soal. Hal ini ditandai dengan kesalahan-kesalahan yang dilakukan subjek Sa dan Sb. Kesulitan yang dialami siswa akan memungkinkan siswa melakukan kesalahan dalam menyelesaikan soal matematika pada setiap pokok bahasan dalam pembelajaran (Untari, 2013).

Pada saat subjek mengerjakan soal, peneliti mengamati aktivitas siswa, pertama-tama setelah diminta mengerjakan soal, siswa membaca soal setelah itu siswa terlihat mengamati soal (membaca dalam waktu singkat beberapa detik) dan mulai mengerjakan.

Subjek Sa dan Sb tidak bisa menggunakan data penting dalam soal yang diberikan. subjek Sa dan $\mathrm{Sb}$ tidak memahami soal yang diberikan, sehingga subjek Sa dan subjek Sb tidak bisa mengubah soal cerita ke dalam bentuk matematika. Subjek Sa dan Sb tidak bisa mengerjakan soal, sehingga subjek Sa dan $\mathrm{Sb}$ tidak bisa mengambil kesimpulan dengan benar.

Subjek Sa dan subjek Sb sering melakukan kesalahan yang sama dalam menyelesaikan soal nomor 1 dan soal nomor 2, yaitu kesalahan dalam menentukan apa yang diketahui dan apa yang ditanyakan, kesalahan dalam menentukan langkah-langkah dalam menyelesaikan soal, kesalahan perhitungan, kesalahan dalam pengambilan kesimpulan.

\section{KESIMPULAN DAN SARAN}

A. Kesimpulan

Berdasarkan hasil penelitian dan pembahasan pada BAB sebelumnya, maka dapat disimpulkan bahwa kesulitan yang dilakukan siswa dalam menyelesaikan soal yaitu :

a. Kesulitan memahami soal.

Dalam kesulitan memahami soal, siswa tidak bisa membedakan apa yang diketahui dan apa yang ditanyakan dalam soal. Tidak bisa mengubah soal kedalam bentuk matematika, terutama dalam membuat gamabar yang terkait dengan soal.

b. Kesulitan merencanakan penyelesaian. 
Dalam kesulitan merencanakan penyelesaian. Siswa tidak bisa menemukan langkah-langkah yang digunakan untuk menyelesaikan soal. Siswa bisa mengerjakan soal yang diberikan namun tidak sesuai dengan langkah-langkah yang benar.

c. Kesulitan melaksanakan perencanaan

Dalam kesulitan melaksanakan perencanaan, siswa sering melakukan kesalahan dalam menggunakan pengoperasian perkalian dan pengurangan. Siswa mengetahui operasi atau metode yang akan digunakan, namun tidak bisa menjumlahkannya.

d. Kesulitan pengambilan kesimpulan

Dalam kesulitan pengambilan kesimpulan, siswa tidak bisa menyelesaikan permasalahan secara tepat dan hasil jawaban akhir tidak sesuai dengan konteks soal.

B. Saran

Disarankan untuk penelitian selanjutnya untuk menganalisis lebih lanjut faktor penyebab kasulitan siswa dalam menyelasaikan soal cerita keliling dan luas lingkaran ditinjau dari peta kognitif.

\section{DAFTAR RUJUKAN}

Ardiyanti., Bharata, H., \& Yunarti, T. (2014). Analisis Kesalahan dalam Mengerjakan Soal Cerita Matematika. Jurnal Pendidikan Matematika Unila, 2(7).

Arifin, Y, T. (2011). Analisis Kesalahan Siswa Kelas VIII SMP Negeri 10 Semarang Tahun Pelajaran 2010/2011 dalam Menyelesaikan Soal Matematika pada Materi Pokok Lingkaran dengan Panduan Kriteria Watson. Semarang: Universitas Negeri Semarang.

Esterberg, K, G. (2002). Qualitative Methods In Social Research. New York: MC Graw Hill.

Eva, W, M. (2011). Analisis Kesalahan Siswa di Kelas VIII B Sekolah Menengah Pertama Kanisius Pakem dalam Mengerjakan Soal Cerita pada Topik Perbandingan Senilai dan Berbalik Nilai Tahun Ajaran 2011/2012. Yogyakarta: Universitas Senata Dharma.

Gafoor, K, A., \& Kurukkan, A. (2015). Learner and Teacher Perception on Difficulties in Teaching Mathematics: Some Implications. Nasional Conference on Mathematics Teaching-Approacher and Challenges. 4(1), 233-242.

Hadar, M, N., Zaslavsky, O., \& Shlomoinbar. (1987). An Empirical Classification Model For Errors in High School Mathematics. Journal For Research In Mathematics Education, 18(1), 3-14.

Hidayah, S. (2016). Analisis Kesalahan Siswa dalam Menyelesaikan Soal Cerita SPLDV Berdasarkan Langkah Penyelesaian Polya. Jurnal Pendidikan, 1.

Imawati, T. (2016). Diagnosis Kesulitan Belajar Matematika Pada Materi Luas dan Keliling Lingkaran di Kelas VIII E SMP Negeri 2 Jatinom. Universitas Sanata Dharma: Yogyakarta.

Jamaris, M. (2014). Kesulitan Belajar: Perspektif, Asesmen, dan Penanggulangannya. Ghalia Indonesia: Bogor.

Juliyanti (2016). Analisis kesalahan siswa dalam menyelesaikan soal cerita matematika materi pecahan pada siswa kelas IV di SD Negeri se-gugus lodan semarang utara. Semarang: Universitas Negeri Semarang.

Kusumaningtyas, Yoga, D. (2014). The Implementation Of Cooperative Learning Based on Newman's Error Analysis Procedures to Improve Students Mathematical Learning Achievement. Prosiding Konferensi Nasional Matematik. XVII - 2014, ITS. 
Lestari, A. P., Hasbi, M., \& Lefrida, R. (2016). Analisis Kesalahan Siswa Kelas IX Dalam Menyelesaikan Soal Cerita Keliling dan Luas Lingkaran di SMP Al-azhar Palu. Jurnal Elektronik Pendidikan Matematika Tadulako. 3(04).

Miles, M, B., Huberman, M, A. (1984). Qualitative Data Analysis: A Sourccebook Of New Methods. London: Sage Publications.

Negoro, ST., \& Harahap, B. (2014). Ensiklopedia matematika. Bogor: Ghalia Indonesia.

Polya, G. (2014). How to Solve It: A New Aspect of Mathematical Methods. New Jersey: Princeton University Press.

Pratikipong, N., \& Nakamura, S. (2006). Analysis of Mathematics Performance of Grade Five Students in Thailand Using Newman Procedure. Journal of International Cooperation in Education. 9(1): 111-122.

Robert, A. (1988). Error Patterns In Computation. New Jersey: Prentice Hall.

Sari, A, W. (2015). Analisis Kesulitan dalam Pemecahan Masalah Matematika Materi Lingkaran Menurut Taksonomi Bloom Ditinjau dari Ranah Kognitif pada Siswa Kelas VIII SMP Negeri 4 Tulungagung. IAIN Tulungagung: Tulungagung.

Sugiyono. 2016. Metode Penelitian Pendidikan. Bandung: Alfabeta.

Suharnan. (2005). Psikologi Kognitif. Surabaya: Srikandi.

Sutriningsih,N. (2015). Pembelajaran lingkaran Melalui Strategi Pemecahan Masalah Sistematis. STKIP Muhammadiyah Pringsewu Lampung.

Tampomas, H. (2006). Matematika Plus SMP Kelas VIII Semester Kedua. Yudhistira.

Trapsilasiwi, D., Setiawani, S., \& Ummah, I. K. (2017). Analisis Kesalahan Pengolahan Matematika dalam Menyelesaiakan Masalah Lingkaran. Pancaran Pendidikan, 5(4), 159-168.

Ugi, L. E. (2016). Analisis Kesalahan Siswa pada Operasi Hitung Campuran Bilangan Bulat dan Alternatif Pemecahannya. Daya Matematis: Jurnal Inovasi Pendidikan Matematika,4(1), 34-50.

Untari, E. (2013). Diagnosis Kesulitan Belajar Pokok Bahasan Pecahan pada Siswa Kelas V Sekolah Dasar. Jurnal Ilmiah STKIP PGRI Ngawi, 13(01), 1-8.

Utami, N, D. (2017). Kesulitan pada Siswa Kelas XI dalam Menyelesaikan Soal Geometri Ditinjau dari Level Berpikir. Surakarta: Universitas Muhammadiyah.

Wibowo, A, T. (2016). Analisis Kesulitan Siswa Kelas VIII C dan VIII F SMP Negeri 2 Piyungan dalam Menyelesaikan Soal Cerita pada Pokok Bahasan Kubus dan Balok. Yogyakarta: Universitas Sanata Dharma.

Zahara, A. C., Hastari, R. C., \& Ma'ruf, H. F. (2016). Analisis Kesalahan dalam Menyelesaikan Soal pada Materi Lingkaran Ditinjau dari Gaya Kognitif Siswa Kelas VIII SMP Negeri 1 Pogalan Semester Genap Tahun Pelajaran 2015/2016. Inspirasi Jurnal Ilmiah Ilmu Sosial, 13(3). 